Оплачко I. О., аспірант (Національний університет водного господарства та природокористування, м. Рівне)

\title{
ПРОБЛЕМИ ТА ПЕРСПЕКТИВИ УПРАВЛІННЯ ДІЯЛЬНІСТЮ ПІДПРИЕМСТВ ЦЕМЕНТНОЇ ПРОМИСЛОВОСТІ В СУЧАСНИХ УМОВАХ
}

У статті досліджено стан розвитку підприємств цементної промисловості. Здійснено оцінку впливу динамічних змін нестабільного ринкового середовища на діяльність підприємств галузі в Україні. Визначено проблеми та перспективи управління діяльністю підприємств у сучасних умовах. На основі розгорнутого аналізу впливу чинників зовнішнього та внутрішнього середовища на ефективність діяльності підприємств і шляхів досягнення ними стратегічного успіху обґрунтовано необхідність перегляду цільових орієнтирів галузі. Окреслено низку передумов, розгляд яких дозволить створити підґрунтя для прийняття ефективних управлінських рішень топменеджментом підприємств.

Ключові слова: цементна галузь, промислові підприємства, аналіз, система управління, антикризове управління.

Постановка проблеми. В умовах суспільних трансформацій промислові підприємства $€$ не лише важливим елементом національної економіки, а й потужним джерелом економічного зростання як окремих галузей, в яких вони функціонують, так і держави у цілому. Цементну галузь ООН розглядає як одну з найважливіших складових, що характеризує рівень розвитку країни. Сучасний стан розвитку промислових підприємств цементної галузі України обумовлений інтеграційними та трансформаційними процесами, що зумовлюють мінливість та невизначеність середовища їх функціонування. Незалежно від розмірів, промислові підприємства все частіше стикаються з факторами прояву кризових явищ, ключовими з яких є: посилення конкуренції з міжнародними виробниками цементних виробів, «недобросовісна» внутрішня конкуренція, нестабільність роботи постачальників ресурсів, порушення логістики поставок готових виробів, значна енергоємність виробництва, непостійність попиту на продукцію підприємств через непрогнозованість будівництва в країні та ін. Наявність численних галузевих факторів кризових явищ, зростання частоти їх прояву, що зумовлюють погіршення показників функціонування підприємств цементної галузі, вимагають формування і ви- 
користання у їх діяльності дієвої системи управління. До того ж, в кризових умовах обмеженості фінансових, інтелектуальних та часових ресурсів така результативна управлінська система має враховувати, окрім традиційних, інноваційні підходи до управління, що дозволяли б знижувати невизначеність зовнішнього середовища та рефлексивно взаємодіяти з суб'єктами ринку для покращення показників функціонування промислових підприємств і посилення їх конкурентних позицій на вітчизняному та міжнародному ринках.

Аналіз останніх досліджень і публікацій. Теоретико-методичні засади управління діяльністю промислових підприємств в сучасних кризових умовах їх функціонування висвітлені в працях таких вітчизняних та зарубіжних вчених, як Д. Грубер, Е. Джеймс, С. Кесаван, М. Мальчик, В. Міцакіс, К. Ру-Дюфор та ін. Різні аспекти функціонування підприємств цементної галузі України знайшли своє відображення у працях науковців І. Ковальчук, П. Лопатьєва, О. Миколюка, О. Столяренка, Т. Топольницької, М. Шнайдера, а також практиків цементної гаузі Д. Барзиловича, Т. Барингольц, І. Бардасової, О. Гончарук, П. Качура, О. Шуляк та ін. Так, І. Ковальчук та О. Миколюк, а також М. Шнайдер досліджували напрями екологічної модернізації підприємств цементної промисловості та управлінські аспекти впровадження у їх діяльності енергоефективних технологій [4]; Т. Топольницька - напрями регулювання зовнішньоекономічної діяльності підприємств цементної галузі [8]; О. Столяренко здійснив аналіз рівня економічної безпеки підприємств цементної галузі [7]; а П. Лопатьєв запропонував модель прогнозування розвитку цементної промисловості України [5].

Невирішені раніше частини загальної проблеми. Беручи до уваги численні наукові розробки, позитивний досвід роботи, накопичений у сфері управління, слід відзначити, що окремі проблеми прикладного характеру залишаються недостатньо дослідженими та методично забезпеченими, потребують подальшого розвитку як у науково-теоретичному, так і практичному аспектах. Зокрема, результати аналізу представлених у літературі напрацювань дозволили зробити висновок про необхідність проведення дослідження проблем та перспектив управління діяльністю підприємств з урахуванням особливостей функціонування цементної галузі в сучасних умовах.

Постановка завдання. Метою статті $€$ аналіз проблем та обгрунтування перспектив управління діяльністю підприємств цементної промисловості в сучасних умовах.

Виклад основного матеріалу. Сучасні умови господарювання промислових підприємств характеризуються високим ступенем ризику та невизначеності. 3 метою забезпечення їх ефективного функ- 
ціонування в таких умовах необхідно розробити дієву систему антикризового управління. При цьому основним чинником ії формування $\epsilon$ врахування специфіки діяльності промислових підприємств, що потребує аналізу галузевих умов їх функціонування. Так, цементна галузь $€$ однією з найважливіших складових національного господарського комплексу, адже від ії стану залежить реалізація проектів будівництва виробничої, транспортної, соціальної інфраструктури, об'єктів житлово-комунальної сфери і, в кінцевому підсумку, - рівень розвитку промисловості країни в цілому. При цьому частка цементної галузі у ВВП України у 2017 р. становила 2,3\% і була однією з найнижчих серед країн Європи, тоді як в сусідній Польщі ця частка становила 9\%, в Німеччині та Франції - 7,8\%, в США - 5,6\%. До того ж, обсяги світового виробництва цементу з кожним роком зростають (табл. 1).

Таблиця 1

Динаміка світового виробництва цементу

\begin{tabular}{|l|c|c|c|c|c|c|c|c|c|c|}
\hline \multirow{2}{*}{ Країна } & \multicolumn{7}{|c|}{ Обсяг виробницта цементу, млн. т } \\
\cline { 2 - 13 } & $\mathbf{2 0 0 8}$ & $\mathbf{2 0 0 9}$ & $\mathbf{2 0 1 0}$ & $\mathbf{2 0 1 1}$ & $\mathbf{2 0 1 2}$ & $\mathbf{2 0 1 3}$ & $\mathbf{2 0 1 4}$ & $\mathbf{2 0 1 5}$ & $\mathbf{2 0 1 6}$ & $\mathbf{2 0 1 7}$ \\
\hline Китай & 1388,4 & 1644 & 1881,9 & 2063,2 & 2210 & 2420 & 2480 & 2350 & 2410 & 2400 \\
\hline Індія & 185 & 205 & 220 & 240 & 270 & 280 & 260 & 270 & 290 & 280 \\
\hline США & 86,3 & 63,9 & 65,2 & 68,6 & 74,9 & 77,4 & 83,2 & 83,4 & 85,9 & 86,3 \\
\hline Туреччина & 51,4 & 54 & 62,7 & 63,4 & 63,9 & 71,3 & 75 & 77 & 77 & 77 \\
\hline Індонезія & 38,5 & 36,9 & 39,5 & 45,2 & 32 & 56 & 65 & 65 & 63 & 66 \\
\hline $\begin{array}{l}\text { Саудівська } \\
\text { Аравія }\end{array}$ & 37,4 & 37,8 & 42,5 & 48 & 50 & 57 & 55 & 55 & 61 & 63 \\
\hline $\begin{array}{l}\text { Південна } \\
\text { Корея }\end{array}$ & 51,7 & 50,1 & 47,4 & 48,2 & 48 & 47,3 & 63,2 & 63 & 55 & 59 \\
\hline Росія & 53,5 & 44,3 & 50,4 & 56,1 & 61,5 & 66,4 & 68,4 & 69 & 56 & 58 \\
\hline Бразилія & 51,6 & 51,7 & 59,1 & 63 & 68,8 & 70 & 72 & 72 & 60 & 54 \\
\hline Японія & 67,6 & 59,6 & 56,6 & 56,4 & 51,3 & 57,4 & 53,8 & 55 & 56 & 53 \\
\hline Мексика & 37,1 & 35,1 & 34,5 & 35,4 & 35,4 & 34,6 & 35 & 40 & 40,8 & 40,2 \\
\hline Німеччина & 33,6 & 30,4 & 29,9 & 33,5 & 32,4 & 31,3 & 32 & 31 & 32,7 & 32,9 \\
\hline Франція & 21,2 & 18,1 & 18 & 19,4 & 18 & 18 & 16 & 16 & 15,9 & 15,8 \\
\hline Італія & 43 & 36,3 & 34,4 & 33,1 & 26 & 23 & 21 & 21 & 19,3 & 20,4 \\
\hline ПАР & 13,4 & 11,8 & 10,9 & 11,2 & 14 & 15 & 14 & 14 & 13,6 & 13,8 \\
\hline Україна & 14,8 & 9,4 & 9,2 & 10,5 & 10 & 10 & 9 & 8 & 9 & 9,4 \\
\hline Інші & 667,50 & 654,4 & 688,5 & 716,5 & 668,8 & 702,2 & 795,4 & 811,2 & 854,8 & 771,2 \\
\hline Всього & 2842 & $3042,83350,7$ & 3611,7 & 3735 & 4036 & 4198 & 4100 & 4200 & 4200 \\
\hline
\end{tabular}

Джерело: складено автором за даними [9; 10]

Провідні цементні підприємства світу виробляють понад 4 млрд т цементу за рік. Швидке зростання потреб у цементній про- 
дукції відбувається, в основному, в нових індустріальних країнах. Так, виробництво цементу в Китаї за останні 10 років збільшилося у 2 рази - у 2008 р. складало 1,39 млрд т, у 2017 р. - 2,4 млрд т (що становить 57,14\% світового виробництва цементу). Значну частку у світовому виробництві цементу займає Індія (у 2017 р. - 6,67\%), а також США $(2,05 \%)$ та Туреччина (1,83\%). Частка України у світовому виробництві цементу становить всього 0,22\% [10]. Найнижчим серед країн Європи є й показник вітчизняного виробництва цементу на душу населення, який у 2017 році становив в Україні 213 кг (при використанні 222 кг), тоді як у Польщі - 489 кг, Німеччині - 342 кг, Росії 374 кг (при використанні 379 кг), Білорусі - 488 кг (при використанні 355 кг) [9].

Цементна галузь є матеріаломісткою, тому вітчизняні цементні підприємства розташовані у районах видобування сировини. До того ж, більшість підприємств цементної галузі України належать іноземному капіталу: Криворізький і Кам'янський цементні заводи - належать німецькій корпорації HeidelbergCement (частка на ринку 13,4\%); ПАТ «Подільський цемент», ПрАТ «Миколаївцемент» та ТОВ «Цемент» - належать ірландському холдингу Cement Roadstone Holdings (частка на ринку - 27,9\%); ПрАТ «Євроцемент-Україна» належить російському промисловому холдингу «Євроцемент груп» (частка на ринку - 11,8\%), володіє найбільшими виробничими потужностями серед заводів в Україні - 4050 тис. т в рік; філії ПрАТ «Дікергофф Цемент Україна» ПАТ «Волинь-Цемент» і ПАТ «Південьцемент» - належать німецькій компанії Dyckerhoff (частка на ринку 18,5\%), яка, в свою чергу, входить до складу італійського конгломерату Buzzi Unicem; ПрАТ «Івано-Франківськцемент» - належить швейцарській компанії Cemln West SA, було найбільшим підприємством за обсягом виробництва в 2017 р. - 2406 тис. т цементу (частка на ринку - 22,6\%); ПП «Київ-Ресурс» - українська компанія (частка на ринку - 2,9\%) [12]. Сумарна частка цих підприємств становила у 2017 році 97,1\% від загального обсягу виробництва. Консолідована частка у виробництві інших компаній склала 2,9\%. У контексті зазначеного слід відмітити, що виробництво цементу, з точки зору кількості продавців на ринку, є олігополізованим через об'єктивні бар'єри необхідність великих вкладень у створення і модернізацію виробництва, витратність власне самого виробництва і значний період окупності вкладеного капіталу. Що є також однією з причин домінування іноземного капіталу в структурі власності цементних підприємств. Про зацікавленість іноземних інвесторів саме у сировинному та первинному переробному секторах свідчить, насамперед, динаміка обсягу інвестицій у них. Проте навіть іноземні інвестиції у функціону- 
вання і розвиток цементного виробництва не призвели до його масового оновлення.

У період з 2008 р. до 2015 р. динаміка обсягу виробництва цементу в Україні була спадною, за винятком 2011 р., коли відзначався позитивний приріст у 13,88\% (рис. 1). У 2016 р. порівняно з 2015 р. обсяг виробництва цементу збільшився на 10,03\%, у 2017 р. порівняно з 2016 р. - на 5,43\%. У 2017 р. серед провідних підприємств цементної галузі, що збільшили обсяг виробництва цементу, були ПрАТ «Євроцемент-Україна» (+95,65\%), ПрАТ «Івано-Франківськцемент» (+2,07\%), ПрАТ «Дікергофф Цемент Україна» (+0,16\%), ПрАТ «Миколаївцемент» $(+0,41 \%)$, тоді як інші підприємства значно скоротили обсяги виробництва (ПрАТ «Хайдельбергцемент Україна» (-18,96\%), ПАТ «Подільський цемент» $(-13,82 \%))$. Відповідна динаміка обсягу виробництва цементу в Україні спричинена, в першу чергу, аналогічною динамікою обсягу виконаних будівельних робіт (рис. 2). Цемент використовується як основний в'яжучий матеріал і як основа для виробництва бетону у будівництві. Відповідно, параметри функціонування і розвитку цементного виробництва значною мірою залежать від стану та динаміки будівельної галузі. Коефіцієнт кореляції (за рівня довіри $\mathrm{p} \leq 0,05$ ) між наведеними динамічними рядами складає 80,3\%, що підтверджує наведений висновок.

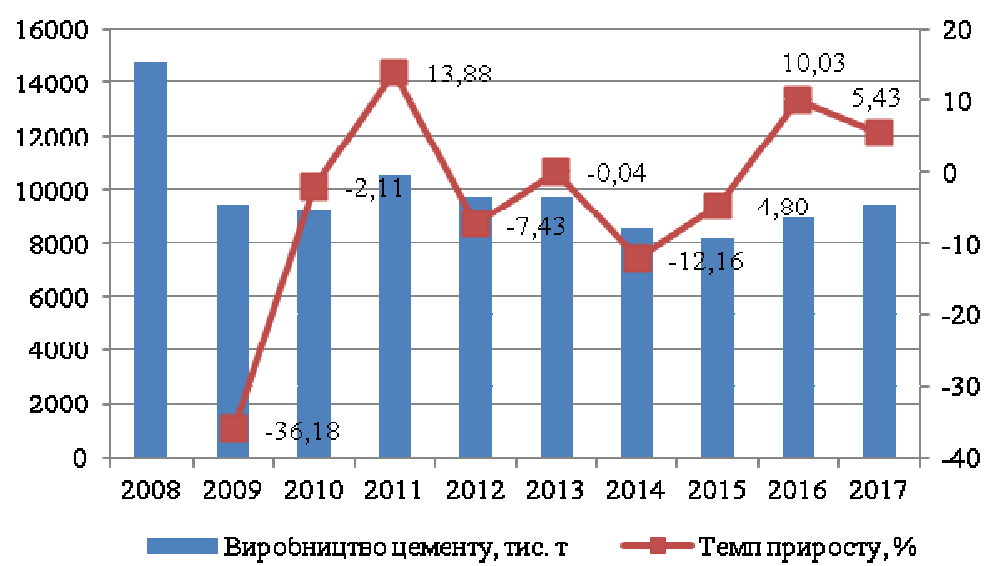

Рис. 1. Динаміка обсягу виробництва цементу в Україні Джерело: складено автором на основі [12] 


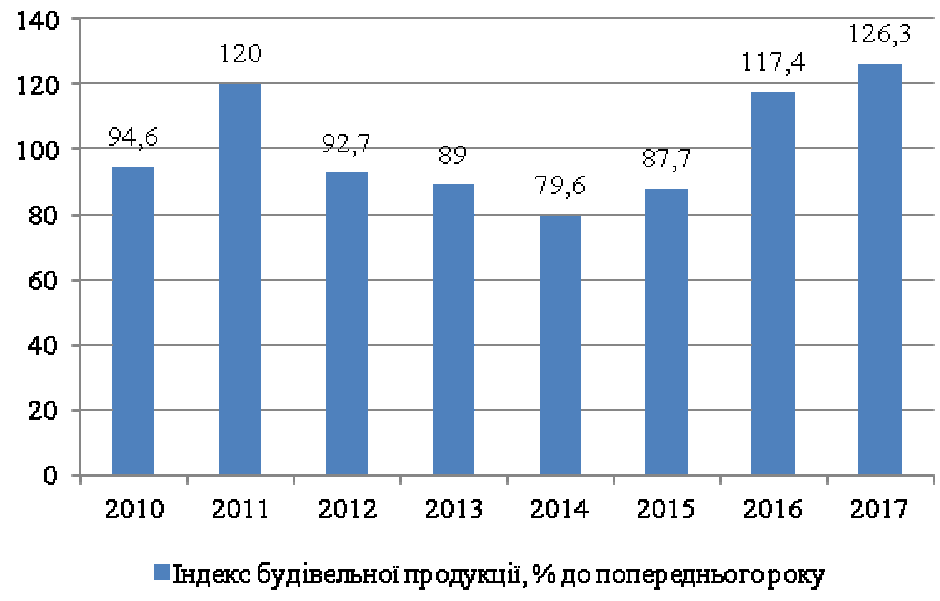

Рис. 2. Динаміка індексу будівельної продукції в Україні Джерело: складено автором на основі [12]

На динаміку обсягу виробництва цементу, починаючи з 2014 р., значний вплив мали військово-політичні події, оскільки три заводи знаходяться на непідконтрольній Україні території (ТОВ «Промцемент», Амвросіївський завод ПАТ «Хайдельбергцемент Україна», ПАТ «Бахчисарайський комбінат «Будіндустрія»). Ще один завод з жовтня 2015 року припинив свою діяльність за рішенням власника (філія «Краматорський ЦЗ-Пушка» ПАТ «Евроцемент-Україна»), внаслідок проблем зі збутом, практика діяльності якого свідчить про те, що для забезпечення ефективного функціонування підприємств цементної галузі необхідно формувати дієву систему антикризового управління, котра б враховувала не лише внутрішні зміни, а й тенденції розвитку галузі та відносини із суб'єктами ринку.

Крім того, несприятлива макроекономічна кон'юнктура визначила зростання цін, а значить, і зменшення попиту на будівельну продукцію та послуги. Наприклад, у 2015 р. ціни на будівельномонтажні роботи в Україні збільшилися на 27,1\% порівняно з 2014 р., у 2016 р. - на 9,2\% порівняно з 2015 р., у 2017 р. - на 13,4\% порівняно з 2016 р., у січні-серпні 2018 р. - на 23,9\% порівняно з аналогічним періодом 2017 р. Причому у 2018 р. зафіксовано найбільше зростання цін на будівельно-монтажні роботи у сфері будівництва транспортних споруд (25,3\%), комплексних промислових споруд (25,9\%) та інженерних споруд (24,8\%), найменше збільшилася вартість будівництва трубопроводів, комунікацій та ліній електропередач - на $21,1 \%$ [12]. Все це об'єктивно впливає на скорочення внутрішнього попиту і обсягів виробництва цементу в Україні. Так, у січні-серпні 2018 р. обсяг виробництва цементу зменшився на 2,9\% порівняно 3 
аналогічним періодом 2017 р., при збільшенні обсягу виконаних будівельних робіт на 5,7\%. Це спричинено також зростанням обсягу продажу дешевої фальсифікованої продукції (згідно дослідження Асоціації виробників цементу «Укрцемент», проведеного у серпні 2018 р., з 50-ти відібраних на ринку мішків цементу 82\% виявилися фальсифікатом, з них 50\% мали нестачу за вагою, 56\% - за критерієм міцності). До того ж, за даними Асоціації «Укрцемент» питома вага залізничного транспорту у логістиці перевезень цементу становить від 60\% до 70\%, на решту видів транспорту припадає відповідно 3040\% [11]. У січні-серпні 2018 р. «Укрзалізниця» виконала лише 56\% замовлень з поставки вагонів цементним підприємствам. «Укрзалізницею» порушуються нормативні строки поставки цементу до споживачів, внаслідок чого штучно створюються зони дефіциту цементу. При цьому вартість залізничних перевезень зростає (у 2018 р. порівняно 32017 р. вартість перевезення хопером-цементовозом збільшилася на 7,2\%, напіввагоном - на 30\%). Це спричинює, окрім внутрішніх загроз, проблеми з експортом цементу вітчизняними підприємствами.

Загальні виробничі потужності всіх вітчизняних підприємств цементної галузі становлять близько 21,4 млн т цементу на рік, а низький рівень їх використання пояснюється високим рівнем морального та фізичного зносу фондів, повільними темпами їх оновлення. Так, у 2008 р. використання виробничих потужностей було максимальним і становило 70,9\%. У післякризовий період до 2015 р. спостерігалася динаміка зменшення цього показника до рівня 40\% (за виключенням 2011 р., коли використання потужностей становило 52,3\%). У 2017 р. використання виробничих потужностей цементних підприємств набуло значення 47,9\% [11].

Серед важливих структурних недоліків цементної галузі слід також виділити енергоємність цементного виробництва (насамперед, виробництва цементного клінкеру), і пов'язану з цим високу енергоємність відходів. Адже на вітчизняних підприємствах використовують переважно застарілий енергоємний «мокрий» спосіб виробництва клінкеру, частка якого хоча й зменшується, проте залишається на високому рівні (у 2017 р. становила 77,78\%).

За різними оцінками, розмір викидів цементного виробництва коливається в діапазоні 0,54-0,83 т діоксиду вуглецю на 1 т цементу [4, С. 6]. Звичайно, що такі обсяги споживання енергії та викидів обумовлюють значну частку витрат в ціні продукції і невелику маржу прибутку. Величина останньої, зокрема, не дає підприємствам змоги змінювати ціну в залежності від попиту на зовнішньому ринку і фор- 
мувати фонд оновлення виробництва.

Щодо зовнішньої торгівлі, то вітчизняний ринок цементу фактично повністю забезпечений продукцією вітчизняного виробництва. Проте частка імпорту в період з 2015 р. стрімко зростає: у 2016 р. порівняно з 2015 р. збільшилася на 40,87\%, у 2017 р. порівняно 3 2016 р. - на 987,19\% (табл. 2). Таке зростання імпорту спричинене, насамперед, збільшенням обсягу імпортованого білоруського цементу (у 2017 р. порівняно з 2016 р. - в 52 рази), частка якого у структурі імпорту становить $80,91 \%$. До того ж, цемент з Білорусі завозився в Україну за демпінговими цінами, що призвело до вимушеного стримування підвищення цін вітчизняними виробниками і, як наслідок, до погіршення фінансових результатів їх діяльності.

Таблиця 2

Структура імпорту вітчизняного цементу у 2014-2017 pp.

\begin{tabular}{|c|c|c|c|c|c|c|c|c|c|c|c|}
\hline \multirow{3}{*}{ Країна } & \multicolumn{8}{|c|}{ Роки } & \multirow{2}{*}{\multicolumn{3}{|c|}{ Темп приросту, \% }} \\
\hline & \multicolumn{2}{|c|}{2014} & \multicolumn{2}{|c|}{2015} & \multicolumn{2}{|c|}{2016} & \multicolumn{2}{|c|}{2017} & & & \\
\hline & тис. т & $\%$ & тис. т & $\%$ & тис. т & $\%$ & тис. т & $\%$ & $\begin{array}{c}2015 / \\
2014\end{array}$ & $\begin{array}{c}2016 / \\
2015\end{array}$ & $\begin{array}{c}2017 / \\
2016\end{array}$ \\
\hline Туреччина & 39,97 & 79,72 & 25,26 & 86,83 & 30,26 & 73,84 & 32,1 & 7,20 & $-36,80$ & 19,79 & 6,08 \\
\hline Білорусь & 2,3 & 4,59 & 1,03 & 3,54 & 6,91 & 16,86 & 360,47 & 80,91 & $-55,22$ & 70,87 & 5116,64 \\
\hline Молдова & 3,78 & 7,54 & - & 0,00 & 0,33 & 0,81 & 44,04 & 9,88 & - & - & 13245,45 \\
\hline Словаччина & 0,73 & 1,46 & 1,21 & 4,16 & 1,29 & 3,15 & 1,34 & 0,30 & 65,75 & 6,61 & 3,88 \\
\hline Польща & 0,85 & 1,70 & 0,57 & 1,96 & 0,94 & 2,29 & 1,15 & 0,26 & $-32,94$ & 64,91 & 22,34 \\
\hline Німе & 0,6 & 1,20 & 0,35 & 1,20 & 0,54 & 1,32 & 1,04 & 0,23 & $-41,67$ & 54,29 & 92,59 \\
\hline Інші & 1,91 & 3,81 & 0,67 & 2,30 & 0,71 & 1,73 & 5,39 & 1,21 & $-64,92$ & 5,97 & 659,15 \\
\hline Bcboro & 50,14 & 100 & 29,09 & 100 & 40,98 & 100 & 445,53 & 100 & $-41,98$ & 40,87 & 987,19 \\
\hline
\end{tabular}

Джерело: складено автором за даними [12]

Щодо імпорту цементного клінкеру, то найбільшу вагу у структурі його імпорту в Україну займав імпорт з Російської Федерації (у 2017 р. 85,45\%). У 2017 р. порівняно з 2016 р. імпорт цементного клінкеру збільшився на 79,19\% до рівня 877,69 тис. т. Внаслідок чого КМУ згідно Постанови № 670 від 29.08.2018 р. вніс цементний клінкер у перелік товарів, заборонених для ввезення на територію України [1]. До того ж, вітчизняні підприємства мають виробничі потужності для заміщення імпортованого клінкеру власним виробництвом: за даними Асоціації «Укрцемент» виробничі потужності по випалюванню клінкеру підприємств України складають 15 млн т, а у 2017 р. ними фактично вироблено всього 6,3 млн т клінкеру [11]. 
Основними експортними ринками збуту вітчизняного цементу у 2017 р. були серед країн СНД Білорусь (20,6\% від загального обсягу експорту у натуральному вигляді) та Молдова (13,64\%), серед інших країн - Румунія $(40,66 \%)$ та Угорщина (23,34\%). Слід відмітити, що в період з 2008 р. до 2017 р. частка експорту до країн СНД у структурі експорту вітчизняного цементу зменшилася з 92,36\% до $34,2 \%$. Це спричинено припиненням постачання цементу до Російської Федерації, а також збільшенням обсягів експорту до країн Європи. Лідером за темпами росту обсягів експорту став ринок Румунії - збільшився в 959 раз у натуральному вигляді.

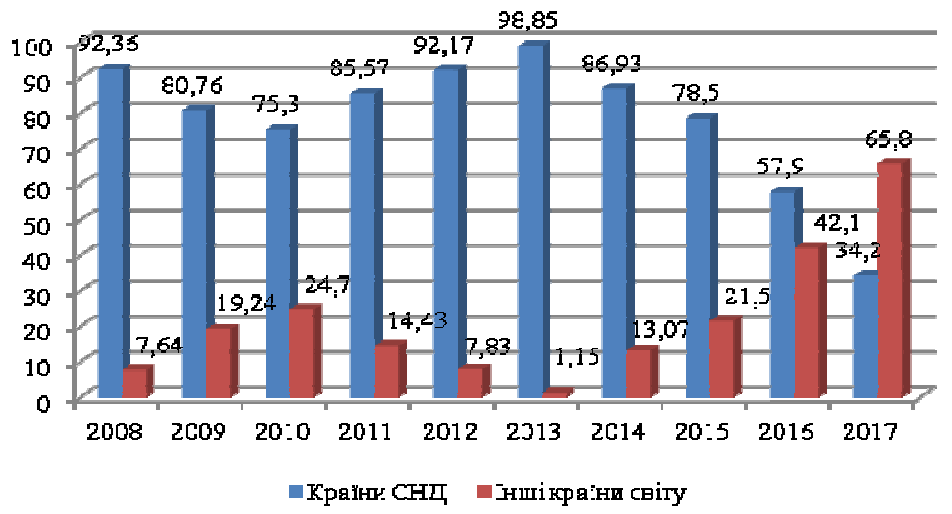

Рис. 3. Структура експорту вітчизняного цементу по країнах у 2008-2017 pp.

Джерело: складено автором на основі [12]

Як зазначає П. Лопатьєв, цементне виробництво - це галузь фактично одного товару, тобто $є$ лише кілька класів цементу і клінкер, як основа для його виробництва, і тому основним елементом збутової політики підприємств галузі виступають ціна продукції та ії якість, а також рівень обслуговування споживачів [5, С. 10]. При цьому важливо враховувати ще одну особливість цементного виробництва низький технологічний рівень продукції [8, С. 778]. Це проявляється, по-перше, у невідповідності вітчизняної продукції цементної промисловості європейським стандартам, по-друге, низьким рівнем виробництва та експорту виробів з цементу (у 2017 р. порівняно з 2016 р. обсяг імпорту виробів з цементу перевищував обсяг експорту вдвічі).

Враховуючи наведені дані, негативною тенденцією функціонування цементної промисловості України $є$ велика частка збиткових підприємств (у 2017 р. - 52\% від загальної кількості підприємств галузі), серед яких одні з найбільших ПрАТ «Хайдельбергцемент Україна» (збиток у 2017 р. становив 430983,00 тис. грн., що на 14,43\% більше порівняно з 2016 р.), ПрАТ «Дікергофф Цемент Україна» (розмір 
збитку у 2017 р. - 316001,00 тис. грн.), ПАТ «Подільський цемент» (збиток у 2017 р. становив 643247,00 тис. грн.), ПрАТ «ЄвроцементУкраїна» (розмір збитку у 2017 р. - 145571,00 тис. грн.) [12]. Що свідчить про необхідність формування (удосконалення) на підприємствах галузі системи антикризового управління на інноваційних засадах.

Висновки. Таким чином, для забезпечення ефективного управління діяльністю промислових підприємств в сучасних умовах, слід враховувати наступні особливості та проблеми їх функціонування у цементній галузі:

- залежність функціонування та розвитку цементного виробництва від стану та динаміки будівельної галузі;

- олігополізоване виробництво цементу, що вимагає значних капіталовкладень для входження в галузь; домінування іноземних інвестицій у структурі капіталу вітчизняних підприємств (при цьому - незначне фінансування оновлення застарілих виробничих потужностей через існування чіткого розподілу ринку та відсутність в поглядах інвесторів перспектив значного зростання внутрішнього ринку);

- висока енергоємність виробництва цементу підприємствами і пов'язана з цим висока енергоємність відходів, значне екологічне навантаження виробництва (при цьому - значна залежність від паливно-енергетичних ресурсів як цінова, так і через обмеженість для виробництва, у зв'язку із дією програм з підвищення національної енергетичної безпеки);

- монопродуктовий характер цементного виробництва і залежність від ресурсного забезпечення, що визначає зорієнтованість збутової політики підприємств галузі на ціну продукції та ії якість, рівень обслуговування споживачів (при цьому - втрата внаслідок військово-політичних подій 2014-2016рр. джерел ресурсного забезпечення на Донбасі та в Криму);

- значна частка транспортних витрат у структурі собівартості вхідних ресурсів та, відповідно, у структурі собівартості готової продукції (при цьому - порушення логістики поставок сировини і готової продукції залізничним транспортом);

- наявність проблем з державним регулюванням імпорту цементу за демпінговими цінами, що створює загрози для діяльності вітчизняних підприємств тощо.

Наявність значної кількості галузевих кризових явищ $є$ однією 3 ключових причин високого рівня збитковості промислових підприємств, для забезпечення ефективного управління якими необхідно створити дієву систему антикризового управління. Така система повинна охоплювати всі ризики діяльності підприємств, а також коор- 
динацію внутрішніх та зовнішніх дій і взаємодій із суб'єктами ринку, забезпечити яку можна шляхом врахування як об'єктивних, так i суб'єктивних чинників прояву кризових явищ. Комплексний підхід до формування системи управління дозволить вищому управлінському персоналу промислових підприємств передати рішення щодо цілей, принципів та механізмів управління таким чином, щоб забезпечити максимально ефективну та швидку розробку і реалізацію програми антикризових дій, а також організовувати рефлексивні впливи на ринкових суб'єктів, з метою за незначних фінансових витрат схилення їх до прийняття рішень, необхідних підприємству.

1. Про внесення зміни до переліку товарів, заборонених до ввезення на митну територію України, що походять з Російської Федерації : Постанова КМУ від 29.08.2018 № 670. URL: http://zakon.rada.gov.ua/laws/show/670-2018\%D0\%BF. (дата звернення: 15.05.2019). 2. Repositioning Crisis Management: The Role of Resilience / D. Gruber, E. James, Ch. Roux-Dufort at al. Academy of Management Proceedings. 2015. № 1. P. 12832. 3. Mitsakis V., Aravopoulou E. The Impact of the Economic Crisis upon Human Resource Development (HRD): Evidence from two Greek Banks. International Journal of HRD Practice, Policy and Research. 2016. № 1(2). P. 67-82. 4. Schnejder M. Technology developments in the cement industry. Cement International. 2015. № 1. P. 212. 5. Лопатьєв П. С. Прогнозування економічного розвитку цементної промисловості України : автореф. дис. ... канд. екон. наук : 08.00.03. Краматорськ, 2015. 20 с. 6. Мальчик М. В., Оплачко І. О. Рефлексивний підхід в системі антикризового управління діяльністю підприємства. Вісник ХНУ. Економічні науки. 2018. № 1. С. 16-20. 7. Столяренко 0. О. Концептуальні засади сценарного управління безпекою функціонування підприємств цементної промисловості. Науковий вісник ЛДУВС. 2017. № 1. С. 145-153. 8. Топольницька Т. Б. Особливості функціонування цементної галузі України в сучасних умовах. Молодий вчений. 2017. № 4 (44). С. 776-779. 9. CEMBUREAU, the European cement association [Electronic resource]. URL : https://cembureau.eu. (дата звернення: 15.05.2019). 10. Statista, the portal for statistics [Electronic resource]. URL : https://www.statista.com. (дата звернення: 15.05.2019). 11. Офіційний сайт Асоціації виробників цементу України «Укрцемент». URL: http://www.ukrcement.com.ua. (дата звернення: 15.05.2019). 12. Офіційний сайт Державної служби статистики України. URL: http://www.ukrstat.gov.ua. (дата звернення: 15.05.2019).

\section{REFERENCES:}

1. Pro vnesennia zminy do pereliku tovariv, zaboronenykh do vvezennia na mytnu terytoriiu Ukrainy, shcho pokhodiat z Rosiiskoi Federatsii : Postanova KMU vid 29.08.2018 № 670. URL: http://zakon.rada.gov.ua/laws/show/670-2018\%D0\%BF. (data zvernennia: 15.05.2019). 2. Repositioning Crisis Management: 
The Role of Resilience / D. Gruber, E. James, Ch. Roux-Dufort at al. Academy of Management Proceedings. 2015. № 1. P. 12832. 3. Mitsakis V., Aravopoulou E. The Impact of the Economic Crisis upon Human Resource Development (HRD): Evidence from two Greek Banks. International Journal of HRD Practice, Policy and Research. 2016. № 1(2). R. 67-82. 4. Schnejder M. Technology developments in the cement industry. Cement International. 2015. № 1. R. 212. 5. Lopatiev P. S. Prohnozuvannia ekonomichnoho rozvytku tsementnoi promyslovosti Ukrainy : avtoref. dys. ... kand. ekon. nauk : 08.00.03. Kramatorsk, 2015. 20 s. 6. Malchyk M. V., Oplachko I. O. Refleksyvnyi pidkhid v sy-stemi antykryzovoho upravlinnia diialnistiu pidpryiemstva. Visnyk KhNU. Ekonomichni nauky. 2018. № 1. S. 16-20. 7. Stoliarenko 0. 0. Kontseptualni zasady stsenarnoho upravlinnia bezpekoiu funktsionuvannia pidpryiemstv tsementnoi promyslovosti. Naukovyi visnyk LDUVS. 2017. № 1. S. 145-153. 8. Topolnytska T. B. Osoblyvosti funktsionuvannia tsementnoi haluzi Ukrainy v suchasnykh umovakh. Molodyi vchenyi. 2017. № 4 (44). S. 776-779. 9. CEMBUREAU, the European cement association [Electronic resource]. URL : https://cembureau.eu. (data zvernennia: 15.05.2019). 10. Statista, the portal for statistics [Electronic resource]. URL : https://www.statista.com. (data zvernennia: 15.05.2019). 11. Ofitsiinyi sait Asotsiatsii vyrobnykiv tsementu Ukrayiny «Ukrtsement». URL: http://www.ukrcement.com.ua. (data zvernennia: 15.05.2019). 12. Ofitsiinyi sait Derzhavnoi sluzhby statystyky Ukrainy. URL: http://www.ukrstat.gov.ua. (data zvernennia: 15.05.2019).

Рецензент: д.е.н., професор Мальчик М. В. (НУВГП)

Oplachko I. O., Post-graduate Student (National University of Water and Environmental Engineering, Rivne)

\section{PROBLEMS AND PROSPECTS OF MANAGEMENT OF ENTERPRISES OF CEMENT INDUSTRY IN MODERN CONDITIONS}

Under conditions of social transformations, industrial enterprises are not only an important element of the national economy but also a powerful source of economic growth as separate sectors in which they operate, as well as, the state as a whole. The cement industry is considered to be by the $\mathrm{UN}$ as one of the most important components that characterizes the level of development of the country. The today's state of development of the industrial enterprises of the cement industry of Ukraine is due to the integration and transformational processes that determine the variability and uncertainty of the environment of their functioning. Independently on size, industrial enterprises are increasingly faced with the manifestation of crisis phenomena. The key ones are increased competition with international cement manufacturers, unfair internal competition, instability of resource suppliers, supply chain disruptions, significant 
energy intensity of production, volatility demand for production of enterprises due to unpredictability of construction in the country, etc. There are numerous sectoral factors of crisis phenomena, increasing the frequency of their manifestations which predetermine the deterioration of the performance indicators of the enterprises in the cement industry. It requires the formation and use of an effective management system in their activities. Moreover, due to financial, intellectual and time-limited constraints, such an effective management system should take into account in addition to traditional, innovative management approaches. It would reduce uncertainty of the environment and reflexively interact with market participants to improve the performance of industrial enterprises and strengthening their competitive position in the domestic and international markets. Therefore, the purpose of the article is to analyze the problems and justify the prospects of managing the activities of the enterprises of the cement industry in modern conditions and can be the basis for the adoption of effective management decisions by top management of enterprises. Keywords: cement industry, industrial enterprises, analysis, management system, crisis management.

Оплачко И. А., аспирант (Национальный университет водного хозяйства и природопользования, г. Ровно)

ПРОБЛЕМЫ И ПЕРСПЕКТИВЫ УПРАВЛЕНИЯ ДЕЯТЕЛЬНОСТЬЮ ПРЕДПРИЯТИЙ ЦЕМЕНТНОЙ ПРОМЫШЛЕННОСТИ В СОВРЕМЕННЫХ условиях

В статье исследовано состояние развития предприятий цементной промышленности. Осуществлена оценка влияния динамических изменений нестабильной рыночной среды на деятельность предприятий отрасли в Украине. Определены проблемы и перспективы управления деятельностью предприятий в современных условиях. На основе развернутого анализа влияния факторов внешней и внутренней среды на эффективность деятельности предприятий и путей достижения ими стратегического успеха обоснована необходимость пересмотра целевых ориентиров отрасли. Очерчен ряд предпосылок, рассмотрение которых позволит создать основу для принятия эффективных управленческих решений топменеджментом предприятий.

Ключевые слова: цементная отрасль, промышленные предприятия, анализ, система управления, антикризисное управление. 